Журнал«Герстективита інновації наукиљ

(Серія«Гедагогіка», Серія«Гцихологія», Серія«Медицинв»

№(6) 2022

УДК 373.2.015.31:613

https://doi.org/10.52058/2786-4952-2022-1(6)-440-451

Волочай Анастасія Олександрівна здобувач вищої освіти освітнього ступеню «Бакалавр», Кременчуцький педагогічний коледж імені А. С. Макаренка, вул. Перемоги 1, кв. 60, м. Кременчук, 39600

Пєчка Лариса Свгенівна кандидат педагогічних наук, доцент кафедри педагогіки та психології дошкільної освіти, Кременчуцький педагогічний коледж імені А. С. Макаренка, вул. Небесної Сотні, 22/13, кв.27, м. Кременчук, 39600, https://orcid.org/0000-0002-2591-6627

\title{
ТЕОРЕТИЧНІ І МЕТОДИЧНІ АСПЕКТИ ДОСЛІДЖЕННЯ ФОРМУВАННЯ ЦІННІСНОГО СТАВЛЕННЯ ДО ВЛАСНОГО ЗДОРОВ'Я ДІТЕЙ СТАРШОГО ДОШКІЛЬНОГО ВІКУ
}

Анотація. У сучасному світі досить гострою постає проблема ціннісного ставлення до здоров'я молодого покоління. Серед причин погіршення стану здоров'я дітей: малорухливий спосіб життя, несприятливі соціальні та психологічні умови життя, незбалансоване харчування, погіршення стану екології, Covid-19 та перехід життя в карантинні умови.

Навчити дітей берегти і зміцнювати своє здоров'я - одне 3 найважливіших завдань сучасних закладів дошкільної освіти. Саме у дошкільному віці формуються життєво необхідні рухові навички, вміння, закладається фундамент здоров'я, розвиваються важливі фізичні якості. У сучасних умовах пандемії особливо важливо вчити піклуватися про своє здоров'я, зміцнювати, зберігати його.

Як зазначено в Законі України «Про дошкільну світу», Базовому компоненті дошкільної освіти, Концепції формування позитивної мотивації на здоровий спосіб життя у дітей та молоді та інших законодавчих і програмних документах - заклади дошкільної освіти повинні створювати необхідні умови для повноцінного фізичного розвитку дітей дошкільного віку.

Важливим для формування ціннісного ставлення до власного здоров'я дітей старшого дошкільного віку є сприйняття ними здоров'я як цінності, що в процесі життєдіяльності набуває особистісної значимості і переходить до особистісних цінностей.

Науковці визначають, що саме в дошкільному віці в процесі активної дитячої діяльності, реально виховати свідоме, бережливе ставлення до власного здоров'я. Тому здоров'збереження стало атрибутом освітнього процесу в дошкільній освіті. Воно виявляється у використанні здоров'язбережувальних технологій, які реалізуються комплексно через створення безпечного розвивального середовища, екологічно сприятливого 440 
життєвого простору, повноцінного медичного обслуговування, харчування, оптимізації рухового режиму, системного підходу до формування в дітей ціннісного ставлення до власного здоров'я і мотивації щодо здорового способу життя, дотримання гармонійних, доброзичливих взаємин між вихованцями.

Ключові слова: цінність, ставлення, здоров’я, діти, старший дошкільний вік

Volochai Anastasiia Oleksandrivna Applicant for Higher Education "Bachelor", Kremenchug Pedagogical College named after AS Makarenko, Victory St., 1, apt. 60, Kremenchuk, 39600

Piechka Larysa Yevhenivna Candidate of Pedagogical Sciences, Associate Professor of the Department of Pedagogy and Psychology of Preschool Education, Kremenchug Pedagogical College named after AS Makarenko, Nebesnoyi Sotni St., 22/13, apt. 27, Kremenchuk, 39600, https://orcid.org/0000-0002-2591-6627

\section{THEORETICAL AND METHODOLOGICAL ASPECTS OF THE RESEARCH ON FORMATION OF VALUABLE ATTITUDE TO THE OWN HEALTH OF CHILDREN OF SENIOR PRESCHOOL AGE}

Abstract. In modern world, the problem of values for the health of the younger generation is quite acute. Reasons for the deterioration of children's health include sedentary lifestyle, unfavorable social and psychological living conditions, unbalanced diet, environmental degradation, Covid-19 and the transition to mass quarantine.

Teaching children to take care of and strengthen their health is one of the most important tasks of modern preschool education. It is at preschool age when the vital motor skills and abilities are formed, the foundation of health is laid, and important physical qualities are developed. In today's pandemic environment, it is especially important to learn how to take care of your health, strengthen it, and preserve it.

As stated in the Law of Ukraine "On Preschool Education", the Basic Component of Preschool Education, the Concept of Positive Motivation for a healthy lifestyle in children and youth and other legislative and policy documentspreschool institutions must create the necessary conditions for full physical development of preschool children.

Children's perception of health as a value is important for the formation of valuable attitude to the own health of older preschool children; as time passes, it acquires personal significance and transitions to personal values.

Scientists claim that it is in the preschool age, during children's activities, that is real to cultivate a conscious, caring attitude to their own health. Therefore, healthcare has become an attribute of the educational process in preschool education. It is manifested in the use of health technologies, which are implemented comprehensively through the creation of a safe development environment, 
environmentally friendly living space, full medical care, nutrition, optimization of physical activity, a systematic approach to forming children's values of their own health and motivation for healthy lifestyle, observance of harmonious, friendly relations between pupils.

Keywords: value, attitude, health, children, senior preschool age

Постановка проблеми. Проблему ціннісного ставлення до здоров'я вивчають досить багато науковців, педагогів у всі часи. I на сьогодні, це актуальна тема для обговорення, особливо в сучасних умовах пандемії. $€$ потреба у новому розгляді і новому погляді до проблеми ціннісного ставлення здоров'я.

Актуальність проблеми стану здоров'я молодого покоління робить категорію «здоров'я» категорією педагогічною і вирішувати іiі в освітній установі необхідно з педагогічних позицій виховання у дитини необхідних особистісних якостей, формування стійкої світоглядної позиції.

Відомим є той факт, що здоров'я, закладене у дитинстві, визначає здоров'я у старші періоди життя людини, те саме можна сказати i про виховання ставлення до нього, систему пріоритетів і переконань особистості. Тематика наукових досліджень доводить, що проблема здоров'я молодого покоління не втрачає з часом своєї актуальності, а набуває характеру глобалізації.

Аналіз останніх досліджень i публікацій. У сучасному світі вже висвітлювалися дослідження про ціннісне ставлення до власного здоров'я дітьми дошкільного віку. Зокрема, проблемі ціннісного ставлення до здоров'я, особливо в період дитинства, присвячено роботи О. Гнізділової, С. Бурсової, Г. Волик, С. Скоропадської, М. Гриньова, О. Кононко, Л. Сварковської, Т. Федорченко. Важливими $є$ праці, що розкривають питання залежності стану здоров'я людини не тільки від зовнішніх чинників, а й від власного ставлення до нього Т. Андрющенко, С. Гаркуша, О. Дубогай, О. Дубасенюк, М. Свтушок та інших.

Проблемі культури здоров'я, формування навичок здорового способу життя, екологічної освіти у вітчизняній педагогіці призначені сучасні наукові дослідження В. Бобрицької, О. Вакуленко, В. Вербицького, Т. Воронцової, В. Горащука, С. Кириленко, Л. Лук’янової, С. Омельченко, В. Оржеховської, Г. Пустовіта, С. Свириденко, С. Страшка, Л. Сущенко, Т. Федорченко.

Сучасні науковці трактують здоров'я як природний стан організму, який характеризується відсутністю будь-яких хворобливих змін, що мають біологічні та соціальні причини. На думку вчених Т. Андрющенко, Т. Бабюк, С. Бабюк, Т. Воднєвої, Г. Григоренко, Н. Синягіна, Л. Пєчки, Ю. Черпака стан здоров'я людини залежить не тільки від зовнішніх чинників, а й від власного ставлення до нього.

Однак, проблема ціннісного ставлення до власного здоров'я дітьми старшого дошкільного віку в сучасному світі потребує нового обгрунтування, яке б змогло краще висвітлити іiі для подальшого вирішення проблеми. 
Мета статті - теоретичне i методичне обгрунтування аспектів дослідження ціннісного ставлення до власного здоров'я дітей старшого дошкільного віку.

Виклад основного матеріалу. У чинному Законі України «Про освіту» першочерговим завданням є здоров'я людини і вільний розвиток особистості. Охорона здоров'я дітей визначається пріоритетною серед діяльності освітньої установи. Здоров'я $є$ умовою успішного росту і розвитку особистості, іiі духовного і фізичного вдосконалення, а в подальшому - успішного життя. Однією з головних завдань дошкільного закладу - створення умов, що гарантують формування і зміцнення здоров'я вихованців [7].

У Законі України «Про дошкільну освіту» наголошується увага на збереження та зміцнення всіх складових здоров'я дитини; формування особистості дитини, розвиток її творчих здібностей, набуття нею соціального досвіду. Педагоги освітніх закладів повинні створити необхідні умови для реалізації визначених завдань [6].

У Базовому компоненті дошкільної освіти формуванню ціннісного ставлення до здоров'я дитини, забезпеченню сприятливих умов для гармонійного фізичного розвитку дитини надається важливого значення: у дошкільному віці відбувається становлення та розвиток організму дитини, формуються життєво необхідні уміння й навички, руховий досвід, розвиваються фізичні якості. Ефективними умовами формування здоров'язбережувальної компетенції дітей є наявність позитивної мотивації на здоров'я.

Водночас аналіз психолого-педагогічної та методичної літератури, не зважаючи на досить вагомі результати наукових пошуків у галузі формування ціннісного ставлення до здоров'я, свідчить, що в сучасних умовах $\epsilon$ потреба у новому теоретичному і практичному опрацюванні даної проблеми. 3 тим, як з'явилися нові реалії сучасного ставлення до здоров'я, стають помітними педагогічні протиріччя між потенційними можливостями дітей дошкільного віку і станом виховної практики, відсутністю методики цілеспрямованого формування ціннісного ставлення до здоров'я у дітей дошкільного віку.

Роль педагога має важливе значення у формуванні ціннісного ставлення до власного здоров'я. Власний приклад педагогів буде стимулювати батьків до активізації у вирішенні проблем здорового способу життя дошкільників. Адже одним із актуальних завдань у практиці роботи ЗДО є забезпечення кваліфікованої допомоги у виробленні навичок збереження, зміцнення і відновлення фізичного, психічного і соціального здоров'я дітей, а також надання дітям знань про основи здоров'я і формування основ ціннісного ставлення до нього $[1,2,8]$.

Для того, щоб сформувати у дітей уявлення про здоровий спосіб життя, насамперед, необхідно сформувати у них свідоме ставлення до власного здоров'я. Відтак, дитина має чітко усвідомлювати значення понять: «Я - фізично здорова», «Я - психічно-здорова», «Я - духовно здорова», «Я - соціально здорова». 
Журнал«Герспективитаінновації наукиљ

(Серія«Гедагогіка», Серія«ГТихологія», Серія«Медицинв»

№1(6) 2022

Л. Пєчка зазначає, що умовами цілісного розвитку дитини є використання в закладі дошкільної освіти здоров'язбережувальних та здоров'яформуючих технологій, які реалізуються комплексно через створення безпечного предметно-розвивального виховного середовища, повноцінного медичного обслуговування, збалансованого харчування, оптимізації активного рухового режиму, системного підходу до формування у дітей ціннісного ставлення до власного здоров'я і мотивації щодо здорового способу життя, а також співпраці з батьками, дотримання доброзичливих взаємин між педагогами та вихованцями, між дітьми [9].

У вихователів закладу дошкільної освіти є лише одна мета - організувати життя та діяльність дитини таким чином, щоб вона могла оволодіти новим статусом - школяр, адекватно реагуючи на зміни у своєму житті. Формування здорової особистості дитини старшого дошкільного віку - це комплексний процес оздоровчого спрямування, що грунтується на взаємодії всіх суб'єктів освітньої діяльності, використанні сучасних засобів організації освіти. Дослідження формування ціннісного ставлення до власного здоров'я дітей старшого дошкільного віку вимагає чітко визначеної, систематизованої роботи.

Для того щоб зрозуміти як сформувати базові навички, які методи, прийоми використати, нами було проведено діагностику сформованості рівнів ціннісного ставлення до власного здоров'я дітей старшого дошкільного віку відповідно до визначених компонентів.

Когнітивний компонент (уявлення, знання, судження про здоров'я, його цінність) визначається в усвідомленні здоров'я як найвищої цінності, його значенні для повноцінної життєдіяльності; знаннях будови, функцій органів й систем організму людини, їх елементарних можливостях, основних чинників збереження здоров'я; знаннях емоційних станів людини, уміння передбачати наслідки дій; розуміння значення загартування для зміцнення здоров'я.

Емоційно-ціннісний компонент регулюється певними мотивами і має емоційне забарвлення. То ж, однією 3 умов формування у дітей старшого дошкільного віку свідомого ставлення до власного здоров'я $\epsilon$ розвиток емоційної чутливості.

Поведінково-діяльнісний компонент - поведінкова реакція, діяльнісна направленість. Діяльність, зумовлена різноманітними мотивами, $\epsilon$ однією 3 найважливіших форм вияву основ ціннісного ставлення дитини до об'єкта або явища.

3 цією метою ми проводили спостереження за поведінкою дітей; бесіди 3 дітьми, батьками та педагогами; ігри, заняття, досліди, моделювання й програвання ситуацій. Вивчення рівня знань дітей старшого дошкільного віку з основ здоровою способу життя проводили шляхом бесід, у процесі яких їм пропонується розкрити власні уявлення про такі поняття із сфери збереження здоров'я, як режим дня, постава, загартування, здорове харчування тощо. При проведенні діагностики враховували, що вихованець розкриває поняття i 
оперує ними. Тому питання формулювали таким чином, щоб відповідаючи на них, дітям було необхідно було не тільки показати розуміння, засвоєння понять, а й дати оцінку своєї готовності до їх застосування.

Розроблені нами завдання для дітей, сприяли визначенню рівня сформованості ціннісного ставлення до власного здоров'я дітей старшого дошкільного віку.

За основу формування питань для дітей старшого дошкільного віку ми брали такі питання: Чи має вихованець знання про здоровий спосіб життя, їх рівень? Чи існують можливості отримати ці знання? Чи знає вихованець, де отримати необхідні знання? Чи усвідомлює він необхідність валеологічних знань?

Аналіз трьох компонентів (когнітивного, емоційно-ціннісного, поведінково-діяльнісного) ціннісного ставлення до власного здоров'я дітей старшого дошкільного віку дозволив зробити висновки.

Когнітивний компонент. Враховуючі визначені питання, ми розробили основні питання, які допомогли нам провести бесіди і діагностику рівнів знань. Було проведено $з$ дітьми бесіди на тему: «Здоров’я людини»; «Хвороби й погані звички»; «Наше тіло».

Проєктивний тест «Здоров'я і хвороба» дозволив виявляти особливості уявлень дітей про здоров'я і хвороби. Звертає на себе увагу детально промальовані зображення хвороби, ніж малюнки, що символізують здоров'я.

Емоційно-ціннісний компонент. Важливу роль у формуванні основ ціннісного ставлення до власного здоров'я у дітей належить батькам. Аналіз роздумів дітей на теми «Що мені потрібно, щоб відчувати себе здоровим» та «Що приносить мені радість?» дозволили виявити залежність позитивного емоційного настрою, що сприяє підтримці здорового самопочуття (почуття комфорту, впевненості в собі, «радість життя») від різних зовнішніх факторів. Діти, які зустрічають розуміння, прийняття зі сторони батьків, однолітків, вихователів, мають адекватну самооцінку, впевненість у собі.

За допомогою ігор ми змогли уточнити рівень сформованості знань дітей про своє здоров'я у таких аспектах: важливість дотримання режимних моментів; важливість знань про власне тіло та його властивості; важливість знань про складові здоров'я та їх вплив на нас. За результатами, які зазначені в таблиці, можемо сказати, що більшість дітей мають недостатній рівень знань в різних сферах здоров'я, ціннісного ставлення до нього, але розуміють, для чого необхідно дотримуватись режиму; обізнані в функціях частин тіла.

Вивчення рівнів сформованості поведінково-діяльнісного компонента ціннісного ставлення до власного здоров'я передбачав визначення ступеня оволодіння дітьми уміннями i навичками здорового способу життя, самостійності, ініціативності, а також виявлення їх здатності до саморегуляції поведінки, адаптації у соціумі, самоконтролю власних почуттів, вчинків. Проведена бесіда спрямована на виявлення елементарних уявлень дітей про здоровий спосіб житті та його дотримання: «Що робити, щоб бути 
Журнал«Герспективитаінноваціїнауки

(Серія«Гедагогіка», Серія«ГЕихологія», Серія«Медицина»

№1(6) 2022

здоровим?»; спілкування вихователя «по телефону» демонструвалось задоволенням дітям, у кого хороший настрій, хороше самопочуття.

Також для того, щоб діагностувати рівні сформованості за компонентами, були проведені дидактичні ігри: «Квітка здоров’я», «Абетка здоров’я», «Режимний ланцюжок».

Дослідження когнітивного компоненту ціннісного ставлення до власного здоров'я продемонстрували, що більшість дітей мають низький рівень прояву даної якості - 70\%; 18\% дітей мають середній; та 12\% дітей мають високий рівень прояву когнітивного компоненту.

Дослідження емоційно-ціннісного компоненту продемонстрували, що більша частина дітей мають низький рівень прояву - 59\%; середній рівень у $19 \%$, низький рівень - у 22\% дітей.

Дослідження поведінково-діяльнісного компоненту продемонстрували, що 45\% дітей демонструють низькі показники, середній - у 35\% дітей, а високий рівень виявився у 20\% вихованців.

Таким чином, за результатами діагностики рівнів сформованості ціннісного ставлення до власного здоров'я дітей старшого дошкільного віку було прийнято рішення розробити методику формування ціннісного ставлення до власного здоров'я дітей старшого дошкільного віку.

Формування ціннісного ставлення до власного здоров’я дітей старшого дошкільного віку передбачає нерозривний i комплексний розгляд цього процесу. Основне завдання - розвиток у дітей усвідомлення цінності здоров'я і здорового способу життя, що сприяють становленню активної особистості. Ми вважаємо, що дитина, у якої буде сформоване сприйняття власного здоров'я як особистісної цінності, намагатиметься свідомо коригувати свою поведінку щодо здорового існування. Тобто, буде бережно ставитися до власного здоров'я і здоров'я оточуючих; прагнути до адекватного сприйняття знань i навичок по його охороні, їх втіленню у повсякденне життя.

Для того щоб досягти поставленої мети і сформувати ціннісне ставлення до власного здоров'я, ми щоденно планували і проводили освітню роботу, використовуючи різні методи і прийоми формування ціннісного ставлення до власного здоров'я старших дошкільників: заняття різних типів, різні види ігор, оздоровчо-профілактичні засоби, художні та фольклорні твори, ілюстрації тощо. Проводили досліди, експерименти, пропонували для проблемні завдання. Спонукали дітей встановлювати зв’язок між станом окремих органів тіла i загальним самопочуттям, робити висновки щодо доцільності дотримання здоров'язберігаючого стилю поведінки за допомогою сюжетно-рольових ігор.

Спільно з дітьми розробляли комплекси ранкової гімнастики на свіжому повітрі із завданнями. У дітей була можливість самостійно демонструвати їх виконання. У процесі спілкування мотивували вихованців до щоденних занять фізичних вправ i дотримання рухового режиму. Підтримували бажання дошкільників організовувати рухливі ігри, придумувати власні 
загальнорозвиваючі вправи. Щодня діти босоніж проходили «Доріжку здоров'я» для профілактики плоскостопості та загартування дитячого організму. Спонукали малоактивних дітей включатися в ігри, розваги.

Дошкільників привчали до самостійного виконання загартовуючих процедур, спонукали батьків до спільної діяльності з дітьми.

У процесі послідовно спланованої роботи, удосконалювали знання щодо безпеки життєдіяльності в процесі моделювання життєвих ситуацій здоров'язберігаючого змісту. Проведення ігор-драматизацій за мотивами українських народних казок, виконання ігрових завдань («Придумай казку», «Закінчи казку» тощо), оповідань чи проблемних ситуацій з пропозицією самостійно їх вирішити та проаналізувати. Наприклад, вихованцям було запропоновано розіграти таку ситуацію: «Ти дуже образив свого другу. Спробуй помиритися з ним». На виховання у дітей уваги, чуйного ставлення до інших людей, справедливо оцінювати позитивні сторони була спрямована наша робота. 3 цією метою пропонувалось скласти розповідь про добрі справи своїх друзів. Систематична робота педагогів у цьому напряму дозволила дітям навчитись співставляти вчинки людей 3 результатами, виокремлювати їх мотиви. Вирішуючи різні завдання, ситуації, у дітей формуються найважливіші цінності.

Також нами було вирішено, що доцільно буде використовувати сучасні здоров'язбережувальні технології для формування здоров'язбережувальної компетентності. Активно включали арт-терапію, музикотерапію для корекції емоційних відхилень, страхів, рухових i мовних розладів, відхилень у поведінці, при комунікативних труднощах; казкотерапію (казка не тільки вчить дітей переживати, радіти, співчувати, сумувати, але і спонукає їх до мовного контакту, дозволяє вільно мріяти і фантазувати), фітбол-гімнастику за методикою відомої української гімнастки Катерини Серебрянської тощо.

Для формування компетентності дітей у сфері психічного здоров'я створили в групі атмосферу шанобливого ставлення до людини, яка вміє підтримувати на належному рівні власне здоров'я, а також піклується про здоров'я інших людей. Середовище, у якому перебували діти, сприяло формуванню навичок здорового способу життя. Проводили різноманітні заходи, що сприяють збереженню психічного здоров'я дошкільників. Створили в групі куточок релаксації, домашньої іграшки тощо. Надавали дітям знання про емоції людини, розвивали вміння контролювати власні негативні емоції, у повсякденному житті закріплювали правила ввічливої поведінки.

У роботі з дітьми із заниженою самооцінкою допомагали різні завдання, які сприяли позитивному ставленню до себе. Включали в повсякденну діяльність бесіди «Що тобі подобається в собі?»; колективні завдання: зробити «ланцюжки вмінь»; психогімнастику; упроваджували метод Ш. Амонашвілі: «відповідь на вушко» тощо. Також використовували у роботі $з$ дошкільниками комплекс психогігієнічних ігор, вправ, наприклад, «Назви своє ім'я» (вчити представляти себе колективу, називати своє ім'я), «Лагідні слова» (виховувати 
доброзичливе ставлення до людей), «Як пройшов сьогодні день?» (формувати вміння аналізувати події, робити висновки).

Ми надавати дошкільникам можливість за власним бажанням повторювати, моделювати і аналізувати ситуації, які сприяють формуванню соціального здоров'я. Розробили ситуації за темами: «Етикет у житті людини», «Я, сім'я і всі люди», «Я і мої друзі» тощо. У значній мірі усвідомити значимість здоров'я допомогло упровадження в роботу народної творчості: прислів'їв, приказок.

Розвиток у дітей емоційної реакції на оздоровчі дії сприяло проведення психолого-педагогічного тренінгу формування культури взаємин: приділялась особлива увага тим дітям, які потребують корекційного впливу на емоційну сферу. Робота була спрямована на ознайомлення дітей з різними емоціями, особливостями їх виявлення, усвідомлення для хорошого самопочуття, мотивації на здоровий спосіб життя. Нами було зроблено акцент на завданнях:: 1) формування цінності здоров'я як провідної; 2) створення в дитячому колективі атмосфери доброзичливості, взаємодопомоги; 3) розвиток елементарних знань адекватно виражати свої емоції, почуття щодо власного здоров'я й здоров'я інших; 4) сприяння у встановленні причинно-наслідкових, смислових зв'язків між подіями життя, своїми переживаннями, адекватно реагувати на різні життєві ситуації, стримуючи негативні емоції; 5) усвідомлення зв'язку своєї самооцінки 3 реальними досягненнями та оцінками авторитетних дорослих.

Під час самостійної художньої діяльності пропонували дітям складати казки і створювати малюнки про те, що допомагає бути здоровим, про чуйність і байдужість, про звички, які зберігають, і які руйнують здоров'я, про дружбу тощо. Малюнки дітей присвячували таким темам: «Я і лікар», «Улюблений куточок природи», «Я і моя сім'я», «Свято в нашій сім'ї» тощо.

Проводили роботу 3 формування ціннісного ставлення до власного здоров'я у тісній співпраці 3 батьками. Запрошували їх до участі в просвітницьких і оздоровчих заходах, що проводяться в ЗДО: батьківських зборах, дискусіях, консультаціях, бесідах, практичних заняттях; Днях здоров'я, Днях відкритих дверей, туристичних походах, спортивних розвагах тощо.

Взаємодію з батьками щодо формування у дітей уявлень про здоровий спосіб життя реалізували в таких формах систематичної роботи як: анкетування, яке проводили з метою виявити участь батьків в оздоровленні дітей у сім’ї, батьківські збори за темою: «Фізичний розвиток дитини в сім'ї та в ЗДО», «Формування уявлень про здоровий спосіб життя у дітей». Консультації за участю фахівців: логопеда, психолога, медичного працівника: «Здоров’я - справа престижна», «Більше уваги поставі»; «Загартовування, його види і користь», «Організація активного відпочинку у різні пори року», «Запобіжні заходи під час Covid-19»; проведення семінарів-практикумів: «Здоров'язбережувальні прийоми формування правильного дихання», «Стилі сімейних відносин i емоційне самопочуття дитини»; поширення наочно- 
текстової інформації: папки, ширми; пам'ятки та буклети в допомогу батькам: «Загартовування дітей у домашніх умовах», «Комплекс вправ для очей», «Елементарні правила захисту від Covid-19».

Поряд 3 просвітницькою роботою намагаємося залучати батьків в освітній процес. В рамках «Дня відкритих дверей» батьки були присутні на заняттях 3 здоров'я збереження: «Допоможи собі сам», «Де ховається здоров'я. Спільно 3 батьками було проведено спортивні свята: «Тато, мама, я - спортивна сім'я», «Спорт - це життя»; дозвілля - «День туризму» (активний відпочинок на природі). Батьки для дітей є найкращим прикладом у всьому.

Важливою складовою також є робота 3 педагогами закладу дошкільної освіти 3 формування у дітей ціннісного ставлення до власного здоров'я. Були проведені: анкетування, тренінги, консультації, круглі столи, семінари, практикуми; ділові ігри, розроблені методичні рекомендацій та практичні поради щодо здоров'язбережувальних технологій та їх використання.

Проведена нами робота 3 дітьми старшого дошкільного віку включала різні види роботи, які сприяли зростанню у вихованців обсягу знань про «здоров'я людини», «здоровий спосіб життя», його основні складники, механізми зміцнення здоров'я, правила здоров'язбережувальної поведінки.

Контрольний етап експерименту передбачав виявлення динаміки рівнів сформованості знань дітей про здоровий спосіб життя, характеристики його прояву. У групах зросла кількість вихованців із високим рівнем сформованості когнітивного компонента основ ціннісного ставлення до власного здоров'я 3 $12 \%$ до 43\%. Середній рівень сформованості когнітивного компонента спостерігається у 44\% - проти $18 \%$. Бачимо позитивну тенденцію до зниження кількості дітей із низьким рівнем сформованості когнітивного компонента - із $70 \%$ до $13 \%$. Тобто, можна сказати, що проведена робота сприяла суттєвому зниженню розбіжності між знаннями вихованців про ціннісне ставлення до власного здоров'я та їх реальною поведінкою.

Емоційна сфера також зазнала позитивних змін. Зокрема зросли показники усвідомлення дітьми значимості виявлення ціннісного ставлення до власного здоров'я. Високий рівень знань виріс з 22\% до 43\%. Середній показник знань також збільшився з 19\% до 45\%. Особливо гарні результати показав низький показник обізнаності, знизившись з 59 \% до 12\%.

Результати дослідження рівнів сформованості здорового способу життя дітей старшого дошкільного віку засвідчують зростання показників рівнів сформованості здорового способу життя після упровадження методики формування ціннісного ставлення до власного здоров'я дітей старшого дошкільного віку.

На наступному етапі ми аналізували рівень сформованості поведінководіяльнісного компонента. Аналіз експериментальних даних дозволяє визначити, що на початку формувального етапу експерименту діти орієнтувалися на виявлення здорового способу життя тільки під контролем дорослого, після формувального етапу експерименту такі дії вони чинили 
Журнал«Герспективита іноваціїнауки

(Серія«Гедагогіка», Серія«ГТихологія», Серія«Медицинв»

№1(6) 2022

самостійно. Кількість вихованців із високим рівнем сформованості поведінкового компонента ціннісного ставлення до власного здоров'я збільшилася 3 20\% до 45\%; середній - $335 \%$ до 46\%. Також можна спостерігати суттєве зменшення кількості дітей із низьким рівнем сформованості поведінкового компонента з 45\% до 9\%. Результати вивчення засвідчують зростання показників рівнів сформованості даного компонента.

Отримані нами результати показали позитивні зміни у характеристиках ціннісного ставлення до власного здоров'я дітей експериментальної групи, у показниках рівнів сформованості основ ціннісного ставлення до власного здоров'я.

Висновки. Отже, на основі аналізу психолого-педагогічних джерел з'ясовано, що стан дослідження проблеми формування ціннісного ставлення до власного здоров'я дітей старшого дошкільного віку набуває особливої актуальності. Щоб забезпечити повноцінний процес формування ціннісного ставлення до власного здоров'я, дошкільників потрібно залучати до нього не тільки дітей, а й батьків та педагогів. Обрані нами форми, методи впливу на свідомість і поведінку вихованців, включення їх до різних видів спільної діяльності сприяли розвитку у них умінь і навичок здорового способу життя.

\section{Лimepamypa:}

1. Андрющенко Т. К. До здоров'я дітей - компетентнісний підхід. Формування здоров'язбережувальної компетентності дошкільнят. Дошкільне виховання, 2014. 11, С. 20-23.

2. Бабюк С. Педагогічні умови фізичного виховання дітей старшого дошкільного віку y взаємодї дошкільного навчального закладу $і$ сім'ї: автореф. дис... канд. пед. наук: 13.00.08. Інститут проблем виховання НАПН України, Київ, 2011.

3. Базовий компонент дошкільної освіти. Взято 3: https://mon.gov.ua/storage/app/media/ rizne/2021/12.01/Pro_novu_redaktsiyu\%20Bazovoho\%20komponenta\%20doshkilnoyi\%20osvity.pdf

4. Богініч О. Л. Фізичне виховання основи здоров'я та безпеки життєдіяльності дітей старшого дошкільного віку: навч.-метод. посібник. Київ: Генеза, 2013.

5. Вільчковський, Е. С. Організація рухового режиму у дошкільному навчальному закладі. Тернопіль: Мандрівець, 2008.

6. Закон України «Про дошкільну освіту». Редакція від 28.09.2017, підстава 2145-19., ст.. 11, п. 2. Взято 3: http://zakon5.rada.gov.ua/laws/show/2628-14

7. Закон України «Про освіту» (Відомості Верховної Ради (ВВР), від 05.09. 2017, № 2145-VIII ).

8. ЛісневькаН. Педагогічні умови створення здоров'язберігаючого середовища в дошкільному навчальному закладi: автореф. дис... канд. психол. наук: 13.00.08. Київський державний педагогічний університет імені М. П. Драгоманова, Київ, 2016.

9. Пєчка Л. Є. Зміст виховання особистості майбутнього педагога-дошкільника в здоров'язбережувальному середовищі педагогічного закладу вищої освіти. Актуальні питання гуманітарних наук: міжвузівський збірник наукових праџь молодих учених Дрогобицького державного педагогічного університету імені Івана Франка. Дрогобич, 2020. 28.

\section{References:}

1. Andriushchenko T. K. (2014). Do zdorovia ditei - kompetentnisnyi pidkhid. Formuvannia zdoroviazberezhuvalnoi kompetentnosti doshkilniat. [Competence approach to children's health. Formation of health-preserving competence of preschool children]. Kyiv: Doshkilne vykhovannia [in Ukrainian]. 
2. Babiuk S. (2011). Pedahohichni umovy fizychnoho vykhovannia ditei starshoho doshkilnoho viku u vzaiemodii doshkilnoho navchalnoho zakladu i simi. []. Kyiv, [in Ukrainian].

3. Bazovyi Pedagogical conditions of physical education of children of senior preschool age in interaction of preschool educational institution and family komponent doshkilnoi osvity. (2021). [The basic component of preschool education]. Kyiv, [in Ukrainian].

4. Bohinich O. L. (2013). Fizychne vykhovannia osnovy zdorovia ta bezpeky zhyttiediialnosti ditei starshoho doshkilnoho viku: [Physical education of the basics of health and safety of life of older preschool children]. Kyiv, Heneza, [in Ukrainian].

5. Vilchkovskyi E. S. (2008). Orhanizatsiia rukhovoho rezhymu u doshkilnomu navchalnomu zakladi. [Organization of motor mode in preschool educational institution]. Ternopil, Mandrivets, [in Ukrainian].

6. Zakon Ukrainy «Pro doshkilnu osvitu». (2017). [Law of Ukraine "On Preschool Education"]. Kyiv, [in Ukrainian].

7. Zakon Ukrainy «Pro osvitu» (2017). [Law of Ukraine "On Education"]. Kyiv, [in Ukrainian].

8. Lisnevka N. (2016). Pedahohichni umovy stvorennia zdoroviazberihaiuchoho seredovyshcha $v$ doshkilnomu navchalnomu zakladi. [Pedagogical conditions for creating a healthy environment in a preschool educational institution]. Kyiv, [in Ukrainian].

9. Piechka L. Ye. (2020). Zmist vykhovannia osobystosti maibutnoho pedahoha-doshkilnyka $v$ zdoroviazberezhuvalnomu seredovyshchi pedahohichnoho zakladu vyshchoi osvity. [The content of education of the personality of the future preschool teacher in the health-preserving environment of the pedagogical institution of higher education]. Drohobych, [in Ukrainian]. 